\title{
THE FEASIBILITY OF IMPLEMENTING THE UNITED NATIONS GUIDING PRINCIPLES ON BUSINESS AND HUMAN RIGHTS IN THE EXTRACTIVE INDUSTRY IN NIGERIA
}

\author{
Oyeniyi Abe*
}

\begin{abstract}
Extractive resource governance has been a challenging task for resource-rich countries in Africa. It has fuelled civil wars, ethnic clashes and underdevelopment in this region. This has turned the so-called resource wealth into resource curse. To address this particularly nauseating challenge, the international community came together to adopt the UN Guiding Principles on Business and Human Rights (GPs). Polarised debate on whether the GPs should be binding or voluntary has slowed down the effective implementation of the Principles. This article argues that while the GPs have been the latest attempt at regulating multinational companies (MNCs), greater emphasis should be placed on the readiness of states to domesticate the Principles. To achieve this, the paper explores various approaches through which the GPs can be crafted into national legislation. It also investigates the different methods through which states can ensure that corporations systemically respect human rights obligations in their areas of operation. In order to restore faith in the whole process, it is necessary to examine how human rights principles can be mainstreamed into corporate practice locally. No doubt, rights-based frameworks, such as the GPs, are needed to ensure that human rights are streamlined in business' projects, policies, and agreements throughout the various stages, including preparation, funding, implementation and monitoring. The issue of corporate liability under international law has had its troubled history, thus, this article argues that MNCs have a heightened responsibility to respect the human rights of the local communities in resourcerich, war-torn zones, particularly in sub-Saharan African, using Nigeria as focal point.
\end{abstract}

Keywords: Guiding principles, business, human rights, multinational companies (MNCs).

doi: http://dx.doi.org/10.4314/jsdlp.v6i2.7

* Doctoral Candidate, Centre for Comparative Law, Faculty of Law, University of Cape Town, South Africa, currently Fulbright Visiting Scholar at Loyola University, Chicago School of Law. oabe@luc.edu. 


\section{INTRODUCTION}

Since 1948, several human rights instruments have been adopted to safeguard the sanctity of human lives. These instruments, collectively referred to as the International Bill of Rights, ${ }^{1}$ did not specifically provide for human rights violations in the context of business activities. The idea that business enterprises must have human rights responsibilities backed up with legal requirements in their spheres of operation is relatively new and still not universally accepted. ${ }^{2}$ Countless expositions have been made concerning states adopting policies aimed at responsible natural resource extraction. These expositions further exacerbate the problem rather than create a solution. ${ }^{3}$ The lack of binding legal and moral frameworks to guide the behaviour of MNCs emerged as one of the global socio-economic problems of developing countries that arose during the late twentieth century. ${ }^{4}$ The rigorous effort to address these problems led to the formulation of the UN Guiding Principles on Business and Human Rights in 2011 (GPs). ${ }^{5}$

In a somewhat geometric progression, the UN set out to regulate corporate bodies. In 1974, the UN established a Centre for Transnational Corporations to draft a Multinational Code of Conduct for Transnational Corporations. ${ }^{6}$ The first part of the Draft Code was completed in 1983 while the other part was completed in 1990 . The Code emphatically placed tremendous obligations on the MNCs to not only respect the laws of the host states but to desist from any form of political or economic interference in the domestic policies of the

1 The Universal Declaration of Human Rights (1948), the International Covenants on Civil and Political Rights (ICCPR) 1966 and the International Covenants on Economic, Social and Cultural Rights (ICESCR) 1966.

2 John G. Ruggie, "Just Business: Multinational Corporations and Human Rights" (2013) (Norton Global Ethics Series). WW Norton \& Company.

3 Some of the problems related to human rights violation in the context of resource extraction include: access to information, water and air pollution, displacement of citizens from their ancestral lands, lack of participation by locals on development initiatives related to their community and further impoverishment of peoples and their community.

4 Mathias Koenig-Archibugi, "Transnational Corporations and Public Accountability" (2004) 39(2) Government and Opposition 240.

5 HR/PUB/11/04, "Guiding Principles on Business and Human Rights, Implementing the United Nations Protect, Respect and Remedy Framework" $<$ www.ohchr.org/Documents/Publications/GuidingPrinciples Business HR_EN.pdf $>$ accessed 28 April 2016. [GPs]

6 See the UN Code of Conduct on Transnational Corporations, 23 I.L.M. 626 (1984). 
host states. ${ }^{7}$ A few years later the Organisation for Economic Cooperation and Development (OECD), recommended some guidelines for MNCs. ${ }^{8}$ The OECD guidelines represent the most detailed attempt at regulating MNCs around that period. ${ }^{9}$ The Guidelines enjoin companies to respect human rights in every country where they operate. Notably, much like other regulations, they were intended to be non-binding. ${ }^{10}$ Moreover, the MNCs were very instrumental to the continued growth of the economies of most of the developed States in the OECD. ${ }^{11}$

Other various non-binding attempts at regulating activities of MNCs include the Kimberley Process Certification Scheme, ${ }^{12}$ the Extractive Industries

7 Steven Ratner, Corporations and Human Rights: A Theory of Legal Responsibility (2001) 111 YLJ 467, 519.

8 OECD (2011), OECD Guidelines for Multinational Enterprises, 2011 Edition, OECD Publishing, Paris. The Guidelines were updated in 2011 for the fifth time since they were first adopted in 1976. See <www.oecd.org/daf/inv/mne/ 48004323.pdf> accessed 16 October 2015.

9 John G. Ruggie, Business and Human Rights: The Evolving International Agenda (2007) 101 AJIL 819, 834.

10 See Larry C Backer, Transnational Corporations' Outward Expression of Inward Self-Constitution: The Enforcement of Human Rights by Apple, Inc. (2013) 20 IJGLS 827 [The OECD system of principles for the management of corporate behaviour beyond the domestic law of states creates a three-dimensional governance "space" through networks of soft law systems developed by complex partnerships between states, international organisations that serve them and global actors, and the global actors that form the core of the regulatory community].

11 See Gunther Teubner, "Self-Constitutionalising TNCs? On the Linkage of 'Private' and 'Public' Corporate Codes of Conduct" (2011) 18 IJGLS 635. [These codes are mere constitutional impulses, which certainly with great influenceinternational organisations send toward TNCs. Whether they indeed coagulate there into binding constitutional norms is not decided by the institutions of the state world but in the inner processes of private organisations]; see also George K. Foster, Investors, States, and Stakeholders: Power Asymmetries in International Investment and the Stabilising Potential of Investment Treaties (2013) 17 LCLR 361 [Investors may also owe self-imposed obligations toward local stakeholders such as OECD].

12 This scheme marks one of the first initiatives to track what is popularly referred to as blood diamonds (diamonds exploited by MNCs, the proceeds of which funds rebel governments against legitimate governments) from being imported from States riddled in conflicts or ethnic wars. Member states would have to certify that any diamonds to be exported are conflict-free before entering the international market. See Kimberly Process Core Document $<$ www.kimberley process.com/en/about> accessed 13 October 2015. See also Holly Cullen, Is there a Future for the Kimberley Process Certification Scheme for Conflict Diamonds? (2013) 12 MLJ 2 [She reiterated the fact that the activism of civil societies brought to limelight the use of diamonds to finance the activities of 
Transparency Initiative, ${ }^{13}$ and the UN Global Compact. ${ }^{14}$ In 2003, the UN adopted the Draft Norms on the Responsibilities of Transnational Corporations and Other Business Enterprises with Regard to Human Rights. ${ }^{15}$ The United Nations Sub-Commission on the Promotion and Protection of Human Rights approved this instrument on 13 August 2003. ${ }^{16}$ As innovative as most of these human rights treaties and UN Principles may be, their implementation across national and international levels have been met with challenges. Concerns around these challenges have led to calls for an approach that

armed rebel groups. The Kimberley Process establishes a certification system for rough diamonds to guarantee they have not been used to fund armed conflict]. 13 The Initiative promotes transparent and accountable management of natural resources. One important objective of this initiative is that countries that implement the initiative agree to disclose information on tax payments, licences, contracts and other things, see <https://eiti.org/eiti> accessed 13 October 2015. To see detailed reports on how revenues from member country's extractive resources are being managed, see EITI Reports < https://eiti.org/countries/ reports $>$ accessed 13 October 2015. Nigeria domesticated its version of this initiative and made it imperative on agencies in the extractive industry to ensure reporting, disclosure and transparency in all revenues from the extractive industry. See about NEITI <http://neiti.org.ng/index.php?q=pages/ secretariat $>$ accessed 13 October 2015.

14 See The World's Largest Corporate Sustainability Initiative <www.unglobal compact.org/what-is-gc $>$ accessed 13 October 2015. See particularly Principles 1 and 2 of the UN Global Compact Principles available at <www.unglobal compact.org/what-is-gc/mission/principles > accessed 13 October 2015. See also Voluntary Principles for Security and Human Rights (2000), which concern extractive sector companies, Code of Conduct for Private Security Service Providers (2010), the OECD Due Diligence Guidelines for Responsible Supply Chains of Minerals from Conflict-Affected and High Risk Areas (2011); The FAO Voluntary Guidelines on the Responsible Governance of Tenure of Land, Fisheries and Forests in the Context of National Food Security (2012).

15 U.N. Doc. E/CN.4/Sub.2/2003/12/Rev.2 (2003). Article 14 of the Draft Norms requires MNCs and other business enterprises to carry out their activities in accordance with national laws, regulations, administrative practices and policies relating to the preservation of the environment of the countries in which they operate, as well as in accordance with relevant international agreements, principles, objectives, responsibilities and standards with regard to the precautionary principles. They are also to conduct their activities in a manner contributing to the wider goal of sustainable development.

16 For a comparative analysis of the draft UN Code of Conduct and the Norms, see the publication of the University of Minnesota Human rights library at < www1.umn.edu/ humanrts/ataglance/compdftun.html> accessed 13 October 2015. 
mainstreams human rights protection into the extraction of natural resources, conduct of business and corporate social responsibility (CSR). ${ }^{17}$

In July 2005, the UN Secretary-General, Kofi Annan, appointed Professor John G. Ruggie as his Special Representative on Business \& Human Rights (SRSG). ${ }^{18}$ The SRSG, after widespread consultations, eventually drafted the GPs. On 16 June 2011, the United Nations Human Rights Council Resolution $17 / 4$, endorsed the GPs for implementing the UN "Protect, Respect and Remedy" Framework. ${ }^{19}$ The GPs provide a distribution of functions between the States (as holders of the obligation to protect the human rights established in international standards) and companies, which are expected to respect these rights in their activities and apply due diligence procedures in this regard, especially when operating in developing countries. ${ }^{20}$ The GPs apply to States and non-state actors. Through the GPs, human rights are harmonised and integrated into legislation, policies and project activities, thereby giving citizens a basis to demand for enforcement. ${ }^{21}$

Observably, implementation has become a challenge for developing countries due to corruption, administrative ineptitude, the need to attract foreign direct investment, weak implementation of the laws in existence and a dearth of laws that can contend with the developments and dynamics of globalisation. ${ }^{22}$ This is especially so in the extractive industries with which

17 Madhumita Chatterji, 'Corporate Social Responsibility in the Indian Context (2014) Corporate social responsibility and sustainability: Emerging trends in developing economies ch 1; Rhona K. Smith, Textbook on International Human Rights (6th Edn, 2014).

18 Special Representative of the Secretary-General on the Issue of Human Rights and Transnational Corporations and Other Business Enterprises, Guiding Principles on Business and Human Rights: Implementing the United Nations "Protect, Respect and Remedy" Framework, U.N. Doc. A/HRC/17/31 (Mar. 21, 2011).

19 UNHCR Res 17/4(2011) UN Doc HR/PUB/11/04.

20 ibid.

21 Larry Cata Backer, "From Institutional Misalignments to Socially Sustainable Governance: The Guiding Principles for the Implementation of the United Nations' 'Protect, Respect and Remedy and the Construction of Inter-Systemic Global Governance" (2012) 25 PMGBDLJ 69 (analysing an example of the framework of the U.N. Guiding Principles on Business and Human Rights), See United Nations, The Human Rights Based Approach to Development Cooperation towards a Common Understanding among UN Agencies (2003) $<$ www.undg.org/archive_docs/6959-The_Human_Rights_Based_Approach_ to_Development_Coopēration_Towards_a_Common_- Undērstanding_ among_UN.pdf $>$ accessed 10 October 2015.

22 See section 11 (5) of the Oil Pipelines Act Cap O7, LFN 2004. 
this article is concerned. This article explores various approaches through which the GPs can be crafted into national legislation for easy implementation domestically. It investigates the different methods through which states can ensure that corporations systemically respect human rights obligations in their areas of operation. No doubt, rights based frameworks, such as the GPs, are needed to ensure that human rights are streamlined in business' projects, policies, and agreements throughout the various stages, including preparation, funding, implementation and monitoring. This article argues that MNCs have a heightened responsibility to respect the human rights of the local communities in resource-rich, conflict-prone zones in sub-Saharan Africa using Nigeria as focal point.

The first section of this article is the introduction, while the second presents case studies of the deleterious effects of the activities of non-state actors. To contextualise the problem, this section presents two case studies in sub-Saharan Africa, Nigeria and South Africa, to show how weak extractive resource governance has led to recurrent violations of the human rights of local communities in particular and the entire citizens in general. Besides, Nigeria and South Africa host the largest MNCs in the continent, however, they have not shown the requisite political will to implement the GPs in its current form. The third section examines the business and human rights agenda focusing on the effectiveness of the GPs. It discusses the different areas Nigeria needs to strengthen its regulatory apparatus to allow for easy implementation of the GPs. Section four highlights the importance of implementing the GPs, thereby avoiding the pitfalls of the GPs. Section five concludes the article. This paper argues that the GPs could be the lens through which human rights standard could be mainstreamed into corporate conduct and practice. The strand that runs through this work suggests that if the issue of business and human rights is not pragmatically addressed, unabated activities of MNCs could produce indirect effects on the operative enjoyment of human rights.

\section{CONTEXTUAL CASE STUDIES FOR THE BUSINESS AND HUMAN RIGHTS DEBATE}

Given that this article deals with extractive resource governance, two case studies are highlighted to indicate the deleterious effects of the activities of the MNCs. The essence is to justify that while initiatives, rules and visions, are needed to ensure effective governance, concerted efforts should aim at implementing and adapting those principles to the local community who suffer from the deleterious effects of exploitation. 


\subsection{Case Studies}

\subsubsection{Niger Delta: The Ogoni Experience (Nigeria)}

One community that has suffered tremendous degradation in the Niger Delta region of Nigeria with remarkable attention in literature is the Ogoni region. This community has been able to achieve its crusade against the then Nigeria's military junta, through social coalition such as the Movement for the Survival of Ogoni People (MOSOP) ${ }^{23}$ The comprehensive United Nations Environment Programme (UNEP) report in its assessment of about 200 locations in Ogoni, found that due to the decades of oil exploration and blowouts, oil spillage, oil slicks, gas flaring and waste discharge, the once alluvial soil of the Niger Delta is no longer viable for agricultural use and attributes to widespread land degradation. ${ }^{24}$

The world-renowned activist and environmentalist, Ken Saro-Wiwa, led MOSOP in a non-violent crusade against environmental degradation by the MNCs. In October 1990, MOSOP presented the Ogoni Bill of Rights, a document requesting the political and economic emancipation of the Ogoni people. Saro-Wiwa's efforts on several occasions accused the Nigerian government, Shell and Chevron of waging environmental wars and genocidal attacks against the Ogonis and indeed the peoples of the Delta. Outraged by the courageous efforts of the Ogoni people as led by MOSOP, the military regime constantly raided the community, resulting into deaths and decapitation of the Ogoni people. In 1995, Ken Saro-Wiwa was accused of complicity in the killing of four Ogoni chiefs. He was sentenced to death by hanging by a special military tribunal. ${ }^{25}$

23 Timothy Hunt, The Politics of Bones: Dr Owens Wiwa and the Struggle for Nigeria's oil (Mcclelland \& Stewart 2006); Human Rights Watch, "The Ogoni Crisis: A Case-Study of Military Repression in Southeastern Nigeria" (1 July 1995) <www.refworld.org/docid/3ae6a7d8c.html> accessed 6 January 2016.

24 UNEP Report, (2011) Environmental Assessment of Ogoniland < http:// postconflict.unep.ch/publications/OEA/ UNEP_OEA.pdf $>$ accessed 6 January 2016.

25 For a detailed literature on Ogoniland, see Olof Lindén \& Pålsson Jonas, Oil Contamination in Ogoniland, Niger Delta (2013) 42(6) AMBIO 685-701; Susana C. Mijares Pena, Human Rights Violations by Canadian Companies abroad: Choc v. Hudbay Minerals, Inc. (2014) 5 WJLS 1; Barisere Rachel Konne, Inadequate Monitoring and Enforcement in the Nigerian Oil Industry: The Case of Shell and Ogoniland (2014) 47 CILJ 181. 


\subsubsection{The Marikana Incident (South Africa)}

The issues surrounding the Ogoni incident also resonated in the Marikana incident. The Marikana incident started as a wildcat strike by workers engaged at a mine owned by a British company, Lonmin. The company had spent large sums of money on a massive programme of expansion leaving it financially vulnerable. The last thing on its mind was a strike from its workers. ${ }^{26}$ The company fired 12,000 South African miners after a protracted strike over wages. This incident led to sporadic strikes across the South African mining sector.

The strike arose out of failed labour standards. Workers and the local communities were not receiving the dividends of mining and good corporate behaviour was absent; youth unemployment was on the increase, the living conditions of the mineworkers was appalling, growing inequalities were evident. ${ }^{27}$ The strike that ensued saw about 44 platinum miners shot dead by the South African police on 16 August 2012. The shootings have been described as a massacre in the South African media and have been compared to the Sharpeville massacre in $1960 .{ }^{28} \mathrm{Up}$ till today, black workers are exploited like slaves, and work as rock drillers. Poverty forces many of them to forget their ambition and leave school. ${ }^{29}$ The average monthly salary of these rock drillers in South Africa is about US\$500. This condemns them to poverty.

\subsection{Concerted Efforts Towards Norm Implementation}

These cases remind us of the culture of impunity by States and MNCs in the extractive resource governance in sub-Saharan Africa. While some countries have done fairly well within this classification, most African states still grapple with leadership issues and bad governance. The polarised debate on whether voluntary or mandatory principles cover what is needed, share the same goal

26 See About us <www.lonmin.com/> accessed 30 January 2016.

27 See SAPA, Lonmin an Example of Exploitation. Business Report (17 August 2012) $<$ www.iol.co.za/ business/companies/lonmin-an-example-of-exploitation1.1365221\#.Vj2FX_mrTIW> accessed 10 January 2016

28 See Marikana Report <http://107.6.66.171/Full\%20Report\%20of\%20the\% 20Marikana\%20Commision \%20of\%20Inquiry.pdf > accessed 30 January 2016; Richard Stupart, The Night before Lonmin's Explanation African Scene $<$ www.africanscene.co.za/2012/08/the-night-before-lonmins-explanation/> accessed 8 January 2016.

29 Liduduma'lingani Mqombothi, Miners Shot Down: May 30, 2014, a haunting and emotional documentary < http://africasacountry.com/2014/05/minersshot-down-a-haunting-and-emotional-documentary/ $>$ accessed 28 January, 2016. 
- to strengthen accountability for business-related abuses. They only adopt significantly different approaches in achieving that goal.

The foregoing is based on two salient observations: Firstly, African states are unwilling to enforce their domestic laws or court judgments when it comes to business and human rights disputes. ${ }^{30}$ Whereas, this is where our efforts should be geared towards. Rather than externalise responsibility and allow the African continent to be treated like permanent children seeking protection from adults who are miles away from their borders, ${ }^{31}$ African leaders should focus attention on domestic implementation of programmes and policies. One would have expected that the Ogoni incident would have been a forgotten history by now. The events associated with that dark era are still recurring in modern times. Gas is still being flared indiscriminately, despite rules and laws prohibiting such. ${ }^{32}$ Pollution of the seas and oceans occur on a daily basis and so much more.

Secondly, MNCs were simply unprepared for the need to manage the risks of causing or contributing to human rights harm through their own activities and business relationships. Hence the numerous litigations against them. The fact that this is being litigated implies the MNCs find it difficult to adapt to changing circumstances under the business and human rights regime. Firms operate in highly challenging contexts. When things go wrong, the companies are quick to blame the local community of sabotage. On the other hand, the indigenous people claim that the companies are not doing enough in terms of being socially responsible. The simple logic, therefore, is if the companies treat the local communities very well, these communities will in turn accept the companies and voluntarily provide security for the firm's installations. The questions that follow, therefore, are why do companies behave the way they do when it comes to respect for human rights? Where the States fail to fulfil their duty of protecting human rights, should firms also contribute to the failure of the State to uphold certain basic minimum standards of behaviour.

30 Jonah Gbemre v. SPDC and Others, Unreported suit no. FHC/B/CS/53/05 (14 November 2005) [The Court indeed, noted that the Attorney-General of Nigeria regrettably did not put up any appearance, and/or defend the proceedings]. For further explication of this case which shows the earliest attempt at seeking judicial enforcement of human rights violation by victims of corporate abuse, see $<$ http://business-humanrights.org/en/gas-flaring-lawsuit-re-oil-companies-innigeria $>$ accessed 16 October, 2015

31 See Doe v. Nestle USA Inc., 738 F.3d 1048; Akpan v. SPDC, C/09/337050 / HA ZA 09-1580, Judgment dated 30 January 2013, delivered by the District Court of The Hague.

32 See section 3 of the Associated Gas Reinjection Act, Cap A25, Laws of the Federation of Nigeria, 2004. 
Is implementation of human rights norms possible in a jurisdiction such as Nigeria? The next section briefly summarises earliest attempts at regulating the business and human rights practice.

\section{THE BUSINESS AND HUMAN RIGHTS AGENDA: RENEWED FOCUS}

\subsection{Are the Guiding Principles Implementable in Nigeria?}

Implementation has become a challenge for Nigeria. The political will is absent due to corruption and a dearth of laws that can contend with the developments and dynamics of globalisation. ${ }^{33}$ In Nigeria, there is a Production Sharing Formula (PSC) between MNCs and the federal government, through its statutory body. ${ }^{34}$ These contracts are shrouded in secrecy. The local people who are direct beneficiaries of the agreement are not consulted..$^{35}$ If there is the needed transparency and accountability, then GPs would naturally be implemented. The lessons of Ogoni do not seem to reverberate in addressing the social and environmental malaise of the continent. When MNCs are interested in mining activities, they must follow the terms laid down by the host country. Mining rights should belong to the indigenous people. If this is enforced, it is almost certain that the most litigants that would be the MNCs as against the local communities. As the next section shows, the GPs do not provide any new obligation for the states besides those already established under international law, it only creates a path for corporate responsibility for human rights violations to be addressed vigorously.

\subsection{Examining the Effectiveness of the GPs}

The aim of this section is to examine the extent to which the GPs, as currently couched, can be streamlined into domestic legislation so as to make them implementable. The GPs are structured along three different pillars. ${ }^{36}$

33 Peter Muchlinski, Multinational Enterprises and the Law (2006) 105; EM Macek, Scratching the corporate back: Why corporations have no incentive to define human rights (2002) 11 MJGT, 101, 104.

34 The Nigerian National Petroleum Corporation is the statutory body of the state government that regulates activities in the oil and gas industry.

35 See About NNPC, Joint Venture Activities <www.nnpcgroup.com/ NNPCBusiness/Upstream Ventures/JointVentureActivities.aspx $>$ accessed 13 October 2015.

$36 \mathrm{HR} / \mathrm{PUB} / 11 / 04$, Guiding Principles on Business and Human Rights, Implementing the United Nations "Protect, Respect and Remedy" Framework $<$ www.ohchr.org/Documents/Publications/GuidingPrinciplesBusiness HR_EN.pdf $>$ accessed 28 April, 2016. [GPs] 


\subsection{Pillar I: The State Duty to Protect Human Rights ${ }^{37}$}

GP 1 states that: "states must protect against human rights abuse within their territory ... including business enterprises. This requires taking appropriate steps to prevent, investigate, punish and redress such abuse through effective policies, legislation, regulations and adjudication." ${ }^{38}$ States are obligated to prevent the occurrence of corporate human rights violations and also provide access to remedies where such violation occurs. ${ }^{39}$ This Pillar also directs states to clearly set out ways to ensure companies domiciled in its territory respect human rights. ${ }^{40}$

In Nigeria, at the point of incorporation of a company, MNCs should be made aware of the GPs by including it in each set of incorporation forms. Furthermore, the GPs indicate that states are not per se responsible for human rights abuse by private actors. ${ }^{41}$ If states are not responsible, and MNCs are mere objects, not subjects, of international law, should their culture of impunity be made to subsist forever? Ratification of treaties does not add cosmetic value to the treaties; it commands a high sacrifice on the part of the state to abide with such treaties. The effect of ratification is to ensure compliance with international human rights rules and ensure that those operating within its space do the same.

Indeed, States have various obligations with respect to human rights. Firstly, they must respect human rights, ${ }^{42}$ secondly, they must protect human rights, ${ }^{43}$ and thirdly, they must fulfil human rights. ${ }^{44}$ Thus, where states fail, as is often the case, to take any proactive or positive action towards fulfilling their human rights obligations, or as the GPs puts it "prevent, investigate, punish and redress private actors' abuse," 45 they would be held accountable for breach of their human rights obligations under international law.

Whether there is a basis or not, moral rules dictate that states have legal, ethical and moral right to control and regulate the extraterritorial activities

37 ibid 3.

38 ibid GP 1.

39 ibid.

40 ibid GP 2.

41 See Commentary to GP 1.

42 HR/PUB/12/02, The Corporate Responsibility to Respect Human Rights: An Interpretative Guide (2012) para 2, question 2, <www.ohchr.org/Documents/ Publications/HR.PUB.12.2_En.pdf> accessed 28 April 2016. 43 ibid.

44 ibid.

45 See commentary to GP 1. 
of companies domiciled in its jurisdiction or territory. ${ }^{46}$ This is the essence of the Alien Tort Statute in the United States, ${ }^{47}$ and the Canadian policy of monitoring the activities of its companies abroad. ${ }^{48}$ In South Africa, the Kings Report of Corporate Governance mandates South African companies to give periodic reports of its activities. The US Foreign Corrupt Practices Act ${ }^{49}$ mandates accounting transparency requirements under the Securities and Exchange Act of 1934 as well as prosecutes bribery and corruption of foreign officials. ${ }^{50}$ The essence of the Act is to prohibit any US Company and its officials, citizens and residents from influencing anyone with personal payments or rewards. ${ }^{51}$ Actions like this guard the reputation of the state.

Nigeria is a signatory to international human rights instruments that should serve as policy indicators for MNCs operating in the country to respect human rights and to safeguard their reputation. Furthermore, GP 3 emphasises the importance of States to enforce laws that have the effect of requiring corporations to respect human rights, ensure that laws and policies governing the creating and ongoing operation of corporations such as company law enables respect for human rights. ${ }^{52}$ Thus, the enforcement of existing laws is key to closing the governance gap created by globalisation.

\subsection{Pillar II: The Corporate Responsibility to Respect Human Rights $^{53}$}

Being a "responsibility", it merely appeals to corporations to ensure that they conduct themselves in good moral conduct in their spheres of operation. The

46 See commentary to GP 2; see also Larry Cata Backer (n 21) 86.

4728 U.S.C. $§ 1350$. The Alien Tort Statute Act is a 1789 United States law that gives US district courts original jurisdiction in civil action which allows foreigners to bring an action for torts committed in violation of the law of nations or a treaty of the United States; See Preamble to the Act. See Kiobel v. Royal Dutch Petroleum Company 133 S. Ct. 1659 (2013).

48 It is instructive to note, however, that the commentary advices states to regulate extraterritorial activities of its companies as this will ensure predictability for business enterprises by providing coherent and consistent messages, and preserving the States own reputation.

4915 U.S.C. S 78dd-1.

50 See Funk Markus, Getting What They Pay For: The Far-reaching Impact of the Dodd-Frank Acts Whistleblower Bounty' Incentives on FCPA Enforcement (2010) 5 (19) White Collar Crime Report 1-3.

51 See Fred Luthans \& Jonathan Doh, International Management Culture, Strategy, and Behaviour (9th Edn, Mc-Graw-Hill 2014).

52 GP 3.

53 ibid 13. 
responsibility on the part of firms to respect human rights is a global standard of expected conduct. ${ }^{54}$ To meet their obligations, firms are required to meet three fundamental principles.

Firstly, firms must have and adhere to a mission statement devoted to human rights compliance. ${ }^{55}$ Most, if not all MNCs, have statements regarding compliance with human rights standards. Mere statements without more, does not guarantee human rights compliance. There must be an effective regulatory regime that provides sanction for violation of human rights standards. These statements are aspirational in nature; therefore, to actualise the policies contained therein, institutional and functional structure must be put in place to achieve human rights compliance. ${ }^{56}$

Secondly, firms must have a due diligence commitment aimed at reducing the risk of compliance with human rights norms. ${ }^{57}$ Companies must assess actual and potential human rights impacts in their spheres of operations. ${ }^{58}$ Where it is seen that they have violated human rights, they should remediate the damage or prevent any potential risk of adverse effects. Indeed, MNCs have the scientific and technological capability to conduct due diligence, but often times they decide not to. Unfortunately, the state is inherently corrupt and lacks the will to enforce its environmental laws against erring companies, more so, the state government is complicit in these violations done by the MNCs. ${ }^{59}$ Despite this, due diligence and environmental impact assessments are important tools for compliance with the GPs. Nigeria should strengthen its environmental impact assessment to ensure that companies conduct due diligence periodically so as to avoid untoward events. To further encourage companies to do this, the Nigerian state can incentivise companies who show commitment to due diligence compliance. ${ }^{60}$

54 See commentary to GP 13.

55 GP 16.

56 See A/HRC/8/5, Report of the Special Representative of the Secretary-General on the Issue of Human Rights and Transnational Corporations and other business Enterprises, John Ruggie (2008) (para 60).

57 GP 17.

58 ibid.

59 Refer to the Ogoni case.

60 See Oliver De Schutter, Anita Ramasastry et al Human Rights Due Diligence: The role of States (2012) 1-64, 59 <http://humanrightsinbusiness.eu/wpcontent/uploads/2015/05/De-Schutter-et-al.-Human-Rights-Due-DiligenceThe-Role-of-States.pdf $>$ accessed 28 April, 2016. 
Under the Environmental Impact Assessment Act, ${ }^{61}$ Nigeria could embark upon criminalising the activities of companies that do not follow the due diligence mandates. Since it is expected that companies are subject to domestic laws, it is expected that this direction will pave the way for the indirect application of the human rights due diligence as contained in the GPs.

Thirdly, firms are expected to comply with all laws and respect internationally recognised human rights within their spheres of operations. ${ }^{62}$ Thus corporations are to treat the risk of causing or contributing to gross human rights abuses as a legal compliance issue wherever they operate. ${ }^{63}$ Even where the domestic laws of a state are inadequate to address the business and human rights challenge, MNCs are enjoined to comply with all known international human rights Principles. MNCs operate in highly challenging contexts. This increases the risks of corporations being complicit in human rights violations, particularly together with security forces funded by the state. Thus, the importance of treating compliance with domestic and international human rights laws, as a legal compliance cannot be far-fetched.

Interestingly, Nigeria has ratified the International Bill of Human Rights. ${ }^{64}$ Corporations, therefore, have no excuse to avoid compliance with domestic and international human rights laws. Complying with these laws guarantees their social licence to operate, even though they may have been legally permitted to conduct business.

\subsection{Pillar III: Access to Remedy}

This Pillar emphasises states' duty to protect against business-related human rights abuse by ensuring through "judicial, administrative, legislative or other appropriate means" ${ }^{\prime 65}$ those affected by such abuse are granted access to effective remedy. ${ }^{66}$ This duty and responsibility falls entirely on the state. There are two main remedies envisaged by this Principle: procedural and substantive ${ }^{67}$ The substantive mechanism takes the form of apology, restitution, rehabilitation, financial or non-financial compensation and punitive

61 Cap E12 LFN, 2004, see section 62.

62 GP 23.

63 GP 23 (c).

64 International Bill of Rights (n 2).

65 GP 25.

66 GP 25.

67 See commentary to GP 25. 
sanctions. ${ }^{68}$ The procedural approach could be a little bit herculean. Considering the level of corruption that has pervaded the Nigerian space, bureaucratic procedural formalities, burden of proof, legal fees, legal representations, corrupt judiciary and other extenuating factors, access to effective remedies through the Nigerian courts could be insurmountable. Thus, states must ensure that an independent and transparent judiciary is in place to ensure implementation of the GPs.

Duty connotes legal obligations that transform into rights for the recipient. Responsibility however denotes a moral act on the part of the corporations. Civil societies and critics of the GPs oppose voluntary implementation of the GPs. ${ }^{69}$ They claim that MNCs choose to respect the laws that suit them, especially if those laws will be financially burdensome to them. ${ }^{70}$ While the concerns of the civil societies are important, it is important to stress that corporations owe a duty (and not responsibility) to obey domestic laws of their host states. Unfortunately, Nigeria does not have a robust regulatory apparatus that guarantees corporate human rights compliance. The next section discusses various approaches through which Nigeria can resolve this dilemma.

\subsection{Regulatory Measures for Implementing the GPs}

\subsubsection{The Nigerian Constitution}

The Nigerian Constitution does not contain a Bill of Rights as contained in other Constitutions in Africa. ${ }^{71}$ The socio-economic rights, which are guarantees for indirect implementation of the GPs, are contained in Chapter

68 See commentary to GP 25.

69 See Surya Deva, Multinationals, Human Rights and International Law: Time to Move beyond the 'State-Centric' Conception? in Jernej Letnar Ėerniè and Tara Van Ho (eds), Direct Human Rights Obligations of Corporations (The Hague: Wolf Legal Publishers, 2015) 33; Pini Pavel Miretski \& Sascha-Dominik Bachmann, "The UN 'Norms on the Responsibility of Transnational Corporations and other Business Enterprises with regard to Human Rights:' A Requiem” (2012) 17 DLR 1-41,37; Jean Marie Kamatali, "The New Guiding Principles on Business and Human Rights' Contribution in ending the Divisive Debate over Human Rights Responsibilities of Companies: is it time for an ICJ Advisory Opinion?" (2011/2012) 20 CJICL 437-463, 441.

70 ibid.

71 Article 8(2) of the South African Constitution, 1996 provides that a Bill of Rights binds a natural or juristic person... Article 20(1) of the Kenyan Constitution, 2010, provides that: The Bill of Rights applies to all law and binds all state organs and all persons. Article 260 defines person to include a company, association ... whether incorporated or unincorporated.' 
II of the Constitution. ${ }^{72}$ Apart from chapter II, the Constitution makes no reference to business and human rights. It is suggested, therefore, that Nigeria's Constitution should guarantee the International Bill of Rights. This Bill of Rights will apply to all persons, corporations inclusive. After all, it is unthinkable that MNCs will violate the Constitution of their host states.

\subsubsection{The Companies and Allied Matters Act, 1990 (CAMA)}

CAMA is the only legal document that regulates corporations in Nigeria. Unfortunately, there is no human rights provision in the 696 sections of the Act. Section 299 provides that: “... where an irregularity has been committed in the course of a company's affairs ... only the company can sue to remedy that wrong and only the company can ratify the irregular conduct. ${ }^{.73}$ Though the company's affairs is subject to different levels of interpretation, it seems from the provisions that where the company engages in violation of human rights, it is only the company that can sue to penalise itself. This is an impossible task. Furthermore, this provision is contained in the part that deals with the protection of minority against illegal and oppressive conduct, ${ }^{74}$ it is difficult to imagine how a company can be progressive in ensuring compliance with the GPs if it would be the violator and the prosecutor at the same time. Indeed, this section envisages shareholders. This also leads to the failure of CAMA to cater for other stakeholders in the company. To this end, the CAMA should be amended and expanded to accommodate the interests of other stakeholders, such as local communities, for companies in the extractive resource industry.

The CAMA provides that Directors should have duty of care towards their shareholders. ${ }^{75}$ It also states that Directors shall act in utmost good faith towards the company. ${ }^{76}$ This implies that the Board of Directors of a company should take rational decisions that will not violate the human rights of the local communities where extractive resource projects are to be located. Directors should consider human rights responsibilities as one of the best

72 Fundamental Objectives and Directive Principles of State Policies. The justiceability of this section has been a subject of debate for decades. The section contains economic, social and cultural rights, such as the rights to environment and health.

73 See section 299 of the Companies and Allied Mattes Act, 1990. ("CAMA").

74 Part X of CAMA.

75 section 279 of CAMA.

76 ibid. 
interests of the company. A good example is South Africa company law. Section 7(a) of the Companies Act of South Africa, 2008, provides that one of the purposes of the Companies Act is to promote compliance with the Bill of Rights as provided for in the Constitution. ${ }^{77}$ Section 15(1) further provides that the Memorandum of Incorporation must be consistent with the Companies Act. ${ }^{78}$ By natural implication, all incorporation documents of a company must commit to human rights standards. To further ensure transparency and accountability, South Africa's Institute of Directors (IoDSA) produced the Kings Report on Corporate Governance in South Africa. ${ }^{79}$ The Report requires companies to issue periodic documents on their social responsibility projects. ${ }^{80}$

Since the CAMA was enacted in Nigeria 26 years ago, it has not undergone any serious amendment procedure. MNCs are consistently becoming monstrous and states in weak zones are becoming weaker as against the MNCs by the day. Nigeria must take the front seat in addressing the business and human rights debate in Africa. It must amend the CAMA to ensure that at the point of incorporation, all extractive resource companies commit to the GPs. The GPs must be printed and given to all companies as part of the incorporation documents. $^{81}$

Thankfully, it seems the judiciary is leaning towards corporate liability for human rights violations. In West v. Jack \& Ors, ${ }^{82}$ the Supreme Court held that it does not matter where the infringement or contravention or threat of contravention is coming from: "no person or body or persons, natural or legal, or institution is exempted from the above provision." ${ }^{\prime 3}$ Thus, all natural and artificial persons are subject to human rights provisions under applicable laws. Furthermore, Nigeria is a signatory to the Convention on the Elimination of Racial Discrimination, ${ }^{84}$ any attempt to subject human beings to torture,

77 Section 7(a) of the Companies Act of South Africa, 2008.

78 Section 15(1) of the Companies Act of South Africa, 2008.

79 See "Kings Code for Governance Principles for South Africa, 2009" < http:// c.ymcdn.com/sites/www. iodsa.co.za/resource/collection/94445006-4F184335-B7FB-7F5A8B23FB3F/King_III_Code_for_Governance_Principles_.pdf $>$ accessed 28 April 2016.

80 ibid.

81 Nigeria's environmental laws creates provisions for recognition of human rights, see Section 7 of the Harmful Waste (Special Criminal Provisions) Act Cap H1 LFN, 2004; section 6 of the Oil in Navigable Waters Act Cap 06 LFN, 2004; section 3(1) and 4 of the Associated Gas Re-Injection Act, Cap 08 LFN 2004, section 62 of Environmental Impact Assessment Act, Cape E12 LFN, 2004.

82 SC. $15 / 2009$.

83 ibid per Ngwuta, J.S.C.

84 Adopted and opened for signature and ratification by General Assembly resolution 2106 (XX, 21 December 1965. 
and inhuman and degrading treatment is a violation of that person's right to dignity, which the Constitution and Convention prohibits. In Peterside v. IMB, ${ }^{85}$ the court rejected the argument that corporations cannot be prosecuted for human rights violations. To this end, it is suggested that chapters II and IV of the Constitution has "both vertical and horizontal application," ${ }^{166}$ hence those provisions bind the state, individuals and corporations.

\subsection{Right to Property}

One of the inalienable rights of every individual is the right to own immoveable property in any place where such individual is legally allowed to reside. ${ }^{87}$ Extractive resource projects have the potential of depriving individuals from this right. Where such projects resort to displacement, no form of compensation is given to the indigenous people. Article 17 of the Universal Declaration of Human Rights recognises the right of individuals to the exclusive possession and use of property. ${ }^{88}$ Article 14 of the African Charter on Human and People's Rights provides that the right to property shall be guaranteed. ${ }^{89}$

Granted that the right to own land is subject to the states capacity to use that land in the interest of the public, the exercise of this discretion must be for the benefit of the indigenous peoples and not the MNCs whose main objective is maximising profit. Sometimes, these lands are taken for political expediency without any form of compensation. To remove indigenes from their ancestral land is despicable, forceful eviction without any form of compensation is morally appalling and ethically shameful. Besides, no form of compensation is taken for wrongful displacement from land without recourse to public interest. ${ }^{90}$ If members of the community had been part of the contractual relationship between MNCs and government, land taken in the interest of the public would have followed due legal process and would have genuinely been in the interest of the public. In SERAC $v$. Nigeria,${ }^{91}$ the Court held that the forceful acquisition of the land belonging to the Ogoni people of Nigeria without compensation was in violation of article 14 of the African Charter on

85 (1993) 2 NWLR (Pt. 278) 377.

86 ICT Access to Justice: Human Rights Abuses Involving Corporations - Federal Republic of Nigeria (2012) 5.

87 Section 43 of the 1999 Constitution of Nigeria, 1999 (as amended).

88 General Assembly Resolution 217 A, 10 December 1948.

89 Adopted 27 June, 1981.

90 Section 28 of the Land Use Act, 1978.

91 (2001) AHRLR 60 (ACHPR 2001). Communication 155/96. 
Human and Peoples Rights. ${ }^{92}$

The extent of the protection of this right in Nigeria is doubtful. Most extractive resource projects are in the interest of the public, employment is generated, community is more developed, and the States get economic incentives to provide basic amenities. On the other hand, the government does not provide for a participatory framework for local community to be consulted or participate in decisions about projects that will result in land grabbing or removal from their ancestral lands. In implementing the GPs, government must include guarantees that project sites and lands have not been indiscriminately acquired, and where procedurally acquired, adequate compensation has been paid to those whose lands have been affected. This policy would prompt states to take the human rights agenda seriously. To achieve this, certain mechanisms must be put in place. Government must clarify the exact duties of MNCs under the Nigerian Constitution and corporate laws. This will help determine the liability of MNCs under the laws earlier analysed.

\section{AVOIDING THE PITFALLS OF RESOURCE WEALTH}

There is no justification for Nigeria to lower its human rights standards so that these MNCs can continue to operate in their countries. Short-term gains are illusory and they undermine longer-term recovery. ${ }^{93}$ The long and uncontrolled governance gaps embolden the MNCs to operate without sanctions or caution.

Extractive resource wealth in Nigeria has led to unstable growth, macroeconomic instability; ${ }^{94}$ high rates of unemployment, poverty and inequality; ${ }^{95}$ environmental degradation; resource-related conflicts ${ }^{96}$ and entrenched corruption. ${ }^{97}$ The so-called resource curse premise captures these

92 ibid.

93 See Paul Stevens \& Evelyn Dietsche, Resource curse: An analysis of causes, experiences and possible ways forward (2008) 36 Energy Policy 58.

94 R.M Auty (ed.) Resource Abundance and Economic Development (2001).

95 M.L. Ross, How Mineral States Can Reduce Inequality in Humphreys, Sachs \& Stiglitz (eds), Escaping The Resource Curse (2007) 24

96 P Collier \& A Hoeffler, On the Incidence of Civil War in Africa (2002) 46(1) JCR 13-28.

97 T L Karl, Ensuring Fairness: The Case for a Transparent Fiscal Social Contract in Humphreys, Sachs \& Stiglitz (eds) Escaping The Resource Curse (2007) 256285; AfDB (2009a) Botswana 2009-2013 Country Strategy Paper. African Development Bank. 
ill effects of resource-dependence in Nigeria. ${ }^{98}$ In contrast, developed countries have demonstrated the capacity to implement and enforce their laws and policies and engage local communities in the extraction of natural resources located in those countries. The issue of environmental pollution, ethnic conflicts and guerrilla warfare in extractive resource rich zones are issues of monumental and humanitarian tragedy.

The GPs state that the primary duty to protect human rights fall on the state. Observably, the Democratic Republic of the Congo (DRC) presents a particularly interesting case. DRC is a resource-rich country. However, it has been engulfed in wars and ethnic conflicts making it difficult to reap the benefits of those resources. Armed groups control the resources, commercial activities are unimpeded and minerals are exported from the country. Therefore, if states are solely charged with human rights obligations, how will the state of DRC effectively protect the activities that go on in the areas controlled by armed groups? There are lots of problems in weak governance zones. Bad actors are in control. States and MNCs (particularly those operating in weak zones) have a duty to ensure that human rights principles are upheld.

The GPs create a responsibility, which introduces a nouvelle outlook on how businesses should think about human rights. The problem with these rules is not that they are inadequate. It is a problem of enforcement. The enforcement regime is either lacking or non-existent. Apart from strengthening local institutions charged with domestic implementation and enforcement of these laws, control measures should be emphasised if an MNC goes to these weak zones. The mere fact that host countries do not enforce their laws should not be an avenue to aid and abet corrupt governments, thereby avoiding human rights enforcements. If these were aggressively enforced against the MNCs, the notorious Ogoni and Marikana disasters would not have occurred. In effect, therefore, if Nigerian government is violating the rights of indigenous peoples of the Niger Delta, MNCs should not be complicit. This complicity rule should also extend to third parties directly responsible to the MNCs. This would erode the application of separate legal personality principle usually used by the MNCs to avoid liability.

98 The resource curse refers to a situation where resource-dependent countries grow slowly, lack economic diversification, suffer from environmental degradation, experience corruption, undergo violent conflict, and local communities, mainly indigenous peoples and women, do not fully participate in decisionmaking. 


\section{CONCLUSION}

This article has considered the implementation of the GPs in Nigeria. It has also argued for the strengthening of Nigeria's domestic laws, especially the Constitution, corporate law and the right to property under the Act, and the Constitution to ensure effective implementation of the GPs. No doubt, implementing the GPs will involve an investigation into corporate abuse, monitoring of corporate conduct and reporting on human rights due diligence. Certainly, these are developments MNCs would resist. Reporting on and monitoring the activities of MNCs is key to implementing the GPs. There must be a tremendous improvement in firms' compliance with human rights standards. This could be achieved through periodic report on the activities of the firm and the creation of a monitoring agency truly devoted to monitoring firms' compliance with human rights standards. Until Nigeria de-emphasises financial incentive as the goal of political governance, turning resource wealth into improved standard of living for the people will only be a mirage. Most sub-Saharan African countries encountered two major challenges which have impacted growth trajectory. First, the timing to bring extractive industries to fruition coincided with the countries' just attained independence or a transition phase, significantly putting the governments to a test. ${ }^{99}$ Instead of development, the newfound wealth soon turned the fragile democracies into autocratic governments. Second, the financial burden occasioned by the huge investment on oil and gas projects deprived the fragile democracies the much-needed financial reprieve to embark on the project. ${ }^{100}$

The Nigerian Constitution guarantees fundamental human rights for all its citizens, including corporations. Corporations can sue to enforce their fundamental human rights to own property or freedom of expression. It is, therefore, unconscionable for corporations to enjoy these rights but fail to bear responsibilities to respect the rights of others under the same Constitution. The starting point is for the company law to impose human rights obligations on MNCs and local companies operating in the extractive resource industry in Nigeria.

99 Gavin Hilson, "Corporate Social Responsibility in the extractive industry: Experiences from developing countries" (2012) 37 Resource Policy 132. 100 ibid. 